in vivo $36: 1-12(2022)$

doi:10.21873/invivo.12671

Review

\title{
Complications of Trans-oral Endoscopic Thyroidectomy Vestibular Approach: A Systematic Review
}

\author{
ELLADA AKRITIDOU ${ }^{1,2}$, GERASIMOS DOURIDAS ${ }^{1}$, ELEFTHERIOS SPARTALIS $^{2,3}$, \\ GERASIMOS TSOUROUFLIS ${ }^{2,3}$, DIMITRIOS DIMITROULIS ${ }^{2,3}$ and NIKOLAOS I. NIKITEAS ${ }^{2,3}$ \\ ${ }^{1}$ Department of Surgery, Thriassio General Hospital, Athens, Greece; \\ ${ }^{2}$ Hellenic Minimally Invasive and Robotic Surgery (MIRS) Study Group, Athens, Greece; \\ ${ }^{3} 2^{\text {nd }}$ Department of Propaedeutic Surgery, Medical School, \\ National and Kapodistrian University of Athens, Athens, Greece
}

\begin{abstract}
This review focuses on complications linked to trans-oral endoscopic thyroidectomy via vestibular approach (TOETVA) and aimed to elucidate the procedure's initial safety profile. According to the Preferred Reporting Items for Systematic Review and Meta-Analyses (PRISMA), Pubmed, Embase, and the Cochrane databases were screened till May 2021. Twenty-eight articles, nine cohorts and nineteen case series, met the inclusion criteria. Procedure-related complications were analyzed, the most important being hypoparathyroidism: transient (range $=0.94-22.2 \%$ ), permanent (range $=1.33-2.22 \%$ ), and recurrent laryngeal nerve injury: transient (range $=1.9-8.8 \%$ ) and permanent (range $=0.59-1.42 \%)$. Surgical trauma related complications, the most prevalent being seroma, emphysema, and hematoma accounted for $2.91 \%$. Null mortality was reported. Although current evolving experience indicates that TOETVA is safe and linked to acceptable complication rates, the method needs to be compared with the gold standard of traditional thyroidectomy in the context of sufficiently numbered cohorts and ultimately randomized controlled trials.
\end{abstract}

Surgical procedures addressing thyroid/parathyroid pathology are common in general surgery. to date, a transverse-ellipsoid incision to the neck, named by the Swiss doctor Emil Theodor Kocher (1841-1917), is utilized to gain

This article is freely accessible online.

Correspondence to: Dr. E. Akritidou, 13 Laodikias Str., 13674 Acharne, Athens, Greece. Tel: +30 6983478283, e-mail: ellasakritidou@yahoo.com

Key Words: Trans-oral, vestibule, thyroid surgery, complications, minimal invasive thyroid surgery, TOETVA, TORTVA, review. access to the thyroid gland. Albeit meticulous suturing, a scar and marks remain in the most visible area of the neck region, a measurable drawback especially for young women (1). Aiming at elimination of this "iatrogenic tattoo", surgeons conceived various minimal invasive endoscopic approaches to operate thyroid. In parallel, vision technology and surgical instruments developed, thus enabling surgeons to perform thyroid surgery from a remote site. Endoscopic and robotic thyroidectomy have evolved during the last decade in the context of minimal invasion pursuing scar-less surgery on the neck. Various proposed remote procedural innovations have been tried such as the axillary, the areola, the breastchest, and the retro-auricular approach (2-4). Of special interest, being the topic of this short review, is a recently developed technique known as the transoral endoscopic thyroidectomy via the inferior vestibule (TOETVA).

TOETVA is a natural orifice transluminal endoscopic surgical procedure, which nowadays has drawn the attention of both "minimal invasivists" and young aged patients interested in ultimate cosmetic outcomes. TOETVA is realized via three internal incisions in the inferior vestibule, (one 10 -mm port for endoscope and two additional 5-mm ports for surgical instruments), thereby avoiding external visible incisions and scars. Carbon dioxide is insufflated under the anterior cervical platysma to create working space extending from the oral vestibule down to the sternal notch. Then, thyroid excisional procedures are executed endoscopically (or robotically assisted, TOVARA) using conventional laparoscopic instruments and energy-based devices (EBD) $(4,5)$.

Compared to other remote approaches, TOETVA claims to be advantageous in terms of cosmetics due to the proximity of entry sites of the working ports to the target organ (thyroid), the median symmetry of the created surgical field and the invisible sites of the scars. On the other hand, the learning curve seems to be more than steep because the 


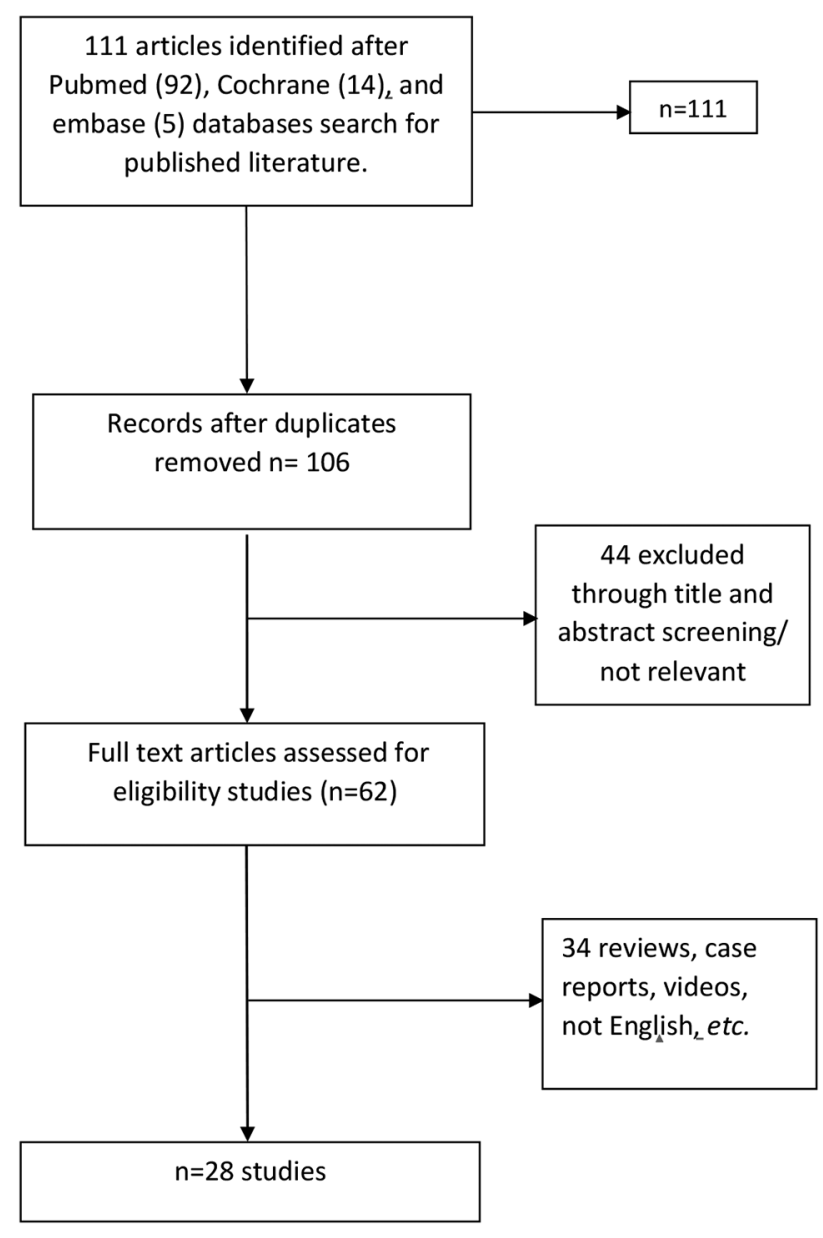

Figure 1. Flowchart: selection of articles.

learner must train his perception to a new "up to down" endoscopic vision in an unexplored till now anatomic area, undoubtfully a great challenge. New laparoscopic skills, tips and tricks had to develop by field pioneers to avoid disastrous surgical complications (5-10). The primary aim of this review was to assess feasibility and safety profile of this modern, minimally invasive thyroid surgical procedure and secondarily to address provisional complications. Whether such an ambitious modern procedure will survive head-tohead comparison with the gold standard of traditional thyroid operation remains to be proven.

\section{Materials and Methods}

Search strategy. Three Databases namely PubMed, EMBASE and Cochrane were meticulously searched for relevant studies. Publication year restrictions were not set and the last search date was May 10, 2021. The search process and elimination steps are both described in Figure 1. Key words used in the electronic research process were: TOETVA, trans-oral vestibular thyroidectomy and complications.
Titles and abstracts were inspected and the articles were discarded if not relevant with complications. Duplicates were identified and discarded. Then, any article within the inclusion criteria set was thoroughly read and analyzed to extract data pertinent with TOETVA complications. Trials published from the same center or author, including different set/number of patients in different time periods were separately recorded and not excluded.

Inclusion and exclusion criteria. Original articles published in English language that assessed or/and described complications following transoral vestibular approach for thyroidectomy were included. Detailed information of patient's characteristics, surgical procedure and peri-operative complications constituted eligibility criteria as well. Articles not written in the English language, reviews, single case reports, letters, abstracts from conferences, videos, and animal or cadaver studies were excluded.

Data recorded. Variables that were extracted from each included study consisted of: author, study type, patient characteristics such as sex and age, diagnosis, type of surgery, operation time, extracted specimen's dimensions and length of hospital stay. Regarding complications the following list was tabulated: recurrent laryngeal nerve, superior laryngeal nerve, mental nerve injuries, transient or permanent, hypoparathyroidism, transient or permanent, surgical site infection, seroma, emphysema, postoperative bleeding, skin flap perforation. Other scarcely reported uncommon complications thus considered miscellaneous were not grouped and thoroughly analyzed (Table I and Table II).

\section{Results}

Twenty-eight eligible studies, the majority of which were of Eastern hemisphere origin, were analyzed. Regarding the type of publication, there were 19 case series and 9 cohorts including 1,887 patients with a mean age of $33.8 \pm 6.6$ years. One thousand seven hundred seventy-six $(1,776)$ were women $(94.22 \%)$ and 111 were men $(5.88 \%)$. Apart from one mixed series of TOETVA and TOVARA, the remaining patients underwent TOETVA. Surgical indications comprised both benign $(n=1088)$ and malignant $(n=799)$ either thyroid or parathyroid diseases namely: graves $(n=78)$, primary hyperparathyroidism $(n=2)$, goiters $(n=583)$ (single or multiple), neoplasms $(n=836)$ (papillary or follicular and atypical), thyroid adenomas and other various benign pathologies $(n=253)$ (cystic nodule, thyroglossal cyst etc.). Type of resections included cyst or nodule resections $(n=3)$, hemithyroidectomy/lobectomies $(n=1174)$, total/almost total thyroidectomy $(n=712)$, parathyroidectomy $(n=2)$. Thyroid resection of neoplasms was occasionally combined with central and/or lateral neck dissection $(n=277)$. Median operation time in minutes was $130 \pm 36.19$ and median length of hospital stay in days was $3.15 \pm 1.47$ hours. Dimension of extracted specimen was expressed either in maximum axis length/diameter $(2.85 \pm 1.98$ $\mathrm{cm})$ or in volume $(30.11 \pm 18.74 \mathrm{ml})$. A wide range of procedurerelated complications were analyzed: (a) Nerve injuries such as recurrent laryngeal nerve (RLN) $(n=85$; transient, 79; permanent 6), superior laryngeal nerve (SLN) $(n=31$; transient, 13 ; 
Table I. Clinical information of patients.

\begin{tabular}{|c|c|c|c|c|c|c|}
\hline ID & Type of article & $\mathrm{N}$ & $\begin{array}{c}\text { Gender } \\
(\mathrm{M} / \mathrm{F})\end{array}$ & Approach & $\begin{array}{c}\text { Age (years) } \\
\text { (median or } \pm \mathrm{SD})\end{array}$ & Diagnosis \\
\hline Karakas E et al. (68) & Case series & 70 & $5 / 65$ & TOETVA/TOVARA & $50(23-74)$ & $2 \mathrm{GD}, 4 \mathrm{PTC}, 2 \mathrm{PH}, 1 \mathrm{TC}$ \\
\hline $\mathrm{Xu} \mathrm{Z}$ et al. (69) & Cohort study & 48 & $4 / 44$ & TOETVA & $30.46 \pm 6.93$ & PTC \\
\hline Tan Y et al. (34) & Case series & 20 & $1 / 19$ & TOETVA & $29.2 \pm 5$ & PTC \\
\hline Wang T et al. (70) & Cohort study & 80 & $0 / 80$ & TOETVA & $31.48 \pm 6.6$ & PTC \\
\hline Guo F et al. (71) & Cohort study & 40 & $0 / 40$ & TOETVA & $29.8 \pm 0.96$ & PTC \\
\hline Kadem SG et al. (72) & Case series & 10 & $0 / 10$ & TOETVA & 30,3 & $\begin{array}{l}1 \mathrm{MG} \\
9 \mathrm{NG}\end{array}$ \\
\hline Ahn JH et al. (21) & Case series & 150 & $5 / 145$ & TOETVA & $43 \pm 10.9$ & 133 PTC,11 FTC, 2A, 4B \\
\hline Park JO et al. (73) & Case series & 15 & $4 / 11$ & $\begin{array}{c}\text { TOETVA } \\
\text { (GASLESS) }\end{array}$ & $42 \pm 10.91$ & $\begin{array}{l}14 \text { PTC } \\
1 \text { FTC }\end{array}$ \\
\hline Peng $\mathrm{X}$ et al. (74) & Cohort study & 105 & $9 / 96$ & TOETVA (MND vs. NMND) & ) $35.5 \pm 10.8$ & $41 \mathrm{NG}, 5 \mathrm{TA}, 58 \mathrm{PTC}, 1 \mathrm{FTC}$ \\
\hline Russell JO et al. (67) & Cohort study & 92 & - & TOETVA & - & - \\
\hline Tesseroli M et al. (75) & Case series & 9 & $0 / 9$ & TOETVA & $33-64$ & $\begin{array}{l}2 \mathrm{PTC} \\
7 \mathrm{~B}\end{array}$ \\
\hline Bian C et al. (76) & Case series & 30 & $1 / 29$ & TOETVA & $24(17-41)$ & 30 PTC \\
\hline Razavi CR et al. (20) & Case series & 30 & $3 / 27$ & TOETVA & $41 \pm 12$ & 2 PTC \\
\hline Wang Y et al. (77) & Case series & 18 & $0 / 18$ & TOETVA & $33(23-45)$ & $\begin{array}{c}10 \text { PTC } \\
5 \mathrm{NG}, 1 \mathrm{FTC}\end{array}$ \\
\hline Bakkar S et al. (23) & Case series & 5 & $0 / 5$ & TOETVA & 36 & $5 \mathrm{NG}$ \\
\hline Anuwong A et al. (19) & Cohort study & 422 & $33 / 389$ & TOETVA & $35.3(16-81)$ & $\begin{array}{c}\text { NG 245, PTC 26, GD } 33 \\
\text { MG118 }\end{array}$ \\
\hline Chen HK et al. (78) & Case series & 20 & $4 / 16$ & TOETVA & $42.05 \pm 10.8$ & 7 PTC, 5 MG, 7 NG \\
\hline Jipratoom P et al. (79) & Cohort studies & 45 & $5 / 40$ & TOETVA & $32.84 \pm 9.0 .1$ & $15 \mathrm{GD}$ \\
\hline Wang Y et al. (6) & Case series & 10 & $1 / 10$ & TOETVA & 32.5 & 10 PTC \\
\hline Sivakumar T et al. (80) & Case series & 11 & $0 / 11$ & TOETVA & 26.5 & $10 \mathrm{MG}, 1 \mathrm{PTC}$ \\
\hline Zhang D et al. (56) & Case series & 41 & $3 / 38$ & TOETVA & $33.7 \pm 10.2$ & $7 \mathrm{NG}, 1 \mathrm{PTC}, 8 \mathrm{NG}$ \\
\hline Lira et al. (81) & Cohort study & 56 & $7 / 49$ & TOETVA & $40.8(16-65)$ & $14 \mathrm{GN}, 42 \mathrm{PTC}$ \\
\hline Le QV et al. (82) & Case series & 28 & $0 / 28$ & TOETVA & $33.8(18-46)$ & $33.8(18-46)$ \\
\hline Dinc B et al. (83) & Case series & 50 & $2 / 50$ & TOETVA & $44(21-76)$ & $38 \mathrm{~B}, 14 \mathrm{PTC}$ \\
\hline Russel JO et al. (84) & Cohort study & 200 & $23 / 177$ & TOETVA & $39(16-71)$ & $30 \mathrm{GD}, 105 \mathrm{~B}, 4 \mathrm{FTC}, 61 \mathrm{M}$ \\
\hline Deroide G et al. (85) & Case series & 90 & $3 / 87$ & TOETVA & $46 \pm 12.4$ & 11 PTC, 13 GD, $46 \mathrm{NG}$ \\
\hline Chai YJ et al. (86) & Case series & 110 & $0 / 110$ & TOETVA & $39.7 \pm 9.7$ & 92 PTC, 8 FTC, 9 NG \\
\hline
\end{tabular}

GD: Grave's disease; PH: primary hyperparathyroidism; PTC: papillary thyroid cancer; TC: thyroglossal cyst; A: atypia; FTC: follicular thyroid cancer; NG: nodular goiter; MG: multinodular goiter; B: benign; M: malignancy; TOETVA: trans-oral endoscopic thyroidectomy via vestibular approach.

permanent, 18), mental nerve $(\mathrm{MN})(\mathrm{n}=102$; transient, 82; permanent, 20), (b) hypo-parathyroidism ( $\mathrm{n}=118 ; 116$ transient, 2 permanent), (c) surgical trauma related complications such as site infection $(n=12)$, seroma $(n=36)$, emphysema $(n=11)$, skin flap perforation $(n=8)$, postoperative bleeding/hematoma $(n=10)$, (d) miscellaneous: tracheal injury $(n=2)$, skin bruise/injury/dimpling $(n=16)$, swallowing discomfort $(n=5)$, long standing pulling sensation $(n=5)$, horner's syndrome $(n=1)$, $\mathrm{CO}_{2}$ embolism $(\mathrm{n}=2)$, dehiscence $(\mathrm{n}=1)$, transient lip drop $(\mathrm{n}=1)$, chin numbness $(n=26)$ (Table III).

\section{Discussion}

Endoscopic and robotic thyroidectomy have evolved during this last decade in the context of minimal invasion pursuing scarless surgery on the neck. Of special interest, is a recently developed technique known as the transoral endoscopic thyroidectomy via the inferior vestibule (TOETVA). TOETVA, is a natural orifice transluminal endoscopic surgical procedure, which nowadays has drawn the attention of both "minimal invasivists" and young aged patients interested in ultimate cosmetic outcomes. A recent study aiming at quantification of social perception of neck scars, utilized eye tracking technology and recorded measurable differences in visual attention attracted by a "marked neck" $(2,3,4,7)$. A long neck, covered by whitecolored skin, free of any scar/mark consists a key feature of perceived attractiveness and facial beauty especially in eastern cultures. This fact might partly explain the fast-growing interest of eastern female patients in minimal invasive techniques of thyroid surgery. Most studies in the literature are of eastern origin and refer to young women. In this review the results of TOETVA refer to a population of 1,887 patients with a mean age of $33.8 \pm 6.6$ years, 1,776 of which were women $(94.22 \%)$ and only 111 were men $(5.88 \%)$. 
Table II. Outcome measures of included studies.

\begin{tabular}{|c|c|c|c|c|}
\hline & $\begin{array}{l}\text { Operation time }(\mathrm{min}) \\
\quad \text { (mean, or } \pm \mathrm{SD} \\
\quad \text { or range })\end{array}$ & $\begin{array}{l}\text { Hospital stay } \\
\quad \text { (days) }\end{array}$ & Operation type & $\begin{array}{l}\text { Specimen "size" } \\
\text { Thyroid volume }(\mathrm{ml} \pm \mathrm{SD}) \\
\text { or size in cm, or diameter } \\
\text { in } \mathrm{cm} \text {, or weight in grams }\end{array}$ \\
\hline Karakas E et al. (68) & $205(96-370)$ & 3 & $\begin{array}{l}39 \text { hemithyroidectomy, } 29 \text { total thyroidectomy, } \\
2 \text { parathyroidectomy, } 1 \text { thyroglossal cyst }\end{array}$ & $\begin{array}{l}<40 \mathrm{ml} 60 \text { patients } \\
>40 \mathrm{ml} 10 \text { patients }\end{array}$ \\
\hline $\mathrm{Xu} \mathrm{Z}$ et al. (69) & $107 \pm 11.8$ & $3.9 \pm 0.4$ & 48 hemithyroidectomy+CND & - \\
\hline Tan Y et al. (34) & $146 \pm 18.7$ & $6.8 \pm 1.3$ & 20 hemithyroidectomy+CND & - \\
\hline Wang T et al. (70) & $193 \pm 47$ & $4(3-5)$ & 80 total thyroidectomies $+\mathrm{CND}$ & Tumor size $0.87 \pm 0.56$ \\
\hline Guo F et al. (71) & $171 \pm 5.34$ & $4.33 \pm 0.88$ & 40 total thyroidectomies $+\mathrm{CND}$ & $\begin{array}{c}\text { Tumor diameter } \\
0.608 \pm 0.034\end{array}$ \\
\hline Kadem SG et al. (72) & 113.5 & 1,7 & 9 lobectomies, 1 total & $\begin{array}{l}\text { Largest dimension } \\
\text { of thyroid lobe } 2.87 \mathrm{~cm}\end{array}$ \\
\hline Ahn JH et al. (21) & $110.26 \pm 35.74$ & $3.64 \pm 1.71$ & 110 lobectomy, 40 total thyroidectomy & Tumor diameter $0.91 \pm 1.00$ \\
\hline Park JO et al. (73) & $135 \pm 45$ & 4.06 & 13 lobectomy, 2 total thyroidectomy & $\begin{array}{c}\text { Tumor size } \\
0.84 \mathrm{~cm}\end{array}$ \\
\hline Peng X et al. (74) & $\begin{array}{c}109.48 \pm 29.8 \\
120 \pm 28.6\end{array}$ & $\begin{array}{l}3.59 \pm 0.94 \\
3.64 \pm 0.68\end{array}$ & $\begin{array}{l}31 \text { hemithyroidectomy } 32 \text { hemithyroidectomy } \\
\text { +CND, } 6 \text { Bilateral thyroidectomies+CND } \\
15 \text { hemithyroidectomy, } 17 \text { hemithyroidectomy } \\
\text { +CND, } 4 \text { Bilateral thyroidectomies+CND }\end{array}$ & $\begin{array}{l}\text { Tumor size } 2.6 \pm 1.6 \\
\text { Tumor size } 2.6 \pm 1.5\end{array}$ \\
\hline Russell JO et al. (67) & $\begin{array}{l}126 \text { (lobectomy) } \\
172.5 \text { (total } \\
\text { thyroidectomy) }\end{array}$ & - & 74 lobectomy, 18 total thyroidectomy & - \\
\hline Tesseroli M et al. (75) & 196.11 & 1.77 & $\begin{array}{l}9 \text { total thyroidectomy } \\
1 \text { partial thyroidectomy }\end{array}$ & Glandular volume $35 \mathrm{ml}$ \\
\hline Bian C et al. (76) & $145(115-240)$ & $3(2-5)$ & 30 unilateral lobectomies+CND & $\begin{array}{l}\text { Tumor diameter } \\
1.5 \mathrm{~cm}(0.3-4.0)\end{array}$ \\
\hline Razavi CR et al. (20) & $136(76-343)$ & - & 30 unilateral lobectomies & $3.3 \mathrm{~cm}$ \\
\hline Wang Y et al. (77) & 124 & 4,05 & $\begin{array}{c}2 \text { total thyroidectomy, } 8 \text { lobectomy, } \\
8 \text { hemithyroidectomy }\end{array}$ & - \\
\hline Bakkar S et al. (23) & 122 & - & 5 hemithyroidectomy & Average nodule size $3.5 \mathrm{~cm}$ \\
\hline Anuwong A et al. (19) & 96.6 & - & $\begin{array}{l}245 \text { hemithyroidectomy, } \\
177 \text { total thyroidectomies }\end{array}$ & $\begin{array}{l}\text { Thyroid lobe size } 6.5 \mathrm{~cm} \\
\text { (median) }\end{array}$ \\
\hline Chen HK et al. (78) & $145 \pm 50.34$ & - & $\begin{array}{l}12 \text { hemithyroidectomy, } \\
8 \text { bilateral thyroidectomies }\end{array}$ & $\begin{array}{c}\text { Mean weight thyroid lobe } \\
17.76 \pm 16.23 \mathrm{~g}\end{array}$ \\
\hline Jipratoom P et al. (79) & $134.11 \pm 31.48$ & - & 45 total thyroidectomies & Mean size $5.41 \pm 1.38$ \\
\hline Wang Y et al. (6) & 191.5 & 4.1 & $\begin{array}{l}1 \text { bilateral thyroidectomy, } \\
9 \text { unilateral thyroidectomy }\end{array}$ & Nodule size $0.5-1.3 \mathrm{~cm}$ \\
\hline Sivakumar T et al. (80) & 130 & 4 & 11 total thyroidectomies & - \\
\hline
\end{tabular}

Various remote access endoscopic thyroidectomy methods have been proposed, however the rather long distance of entry sites from the thyroid bed demanded extensive tissue dissection paths leading to complications and prolonged operative time $(8,11)$.

TOETVA is realized via three internal incisions in the inferior vestibule, (one 10-mm port for endoscope and two additional 5-mm ports for surgery instruments), thereby avoiding external visible incisions and scars. Carbon dioxide is insufflated under the anterior cervical platysma to create a working space extending from the oral vestibule down to the sternal notch. Then, thyroid excisional procedures are executed endoscopically (or robotically assisted) using conventional laparoscopic instruments and energy-based devices $(\mathrm{EBD})(4,5)$. Cosmetics remain the major driving force of procedure's innovation. Conventional thyroidectomy inevitably marks patient's neck. Transoral approach produces no visible incision, neither scar or its physiological variants such as keloid or hypertrophic formation, contracture formation or dehiscence (12-15).

A sufficient number of studies have already been published but long-term follow-up results of TOETVA regarding its surgical and oncologic safety are lacking (16-18). Although preliminary case series report favorable outcomes (19) and shorter learning curves compared to other minimal invasive surgery (MIS) procedures (20), clear and robust data supporting safety issues and a non-inferiority identity compared to conventional thyroidectomy are still pending $(4,21,22)$. Several potential challenges should be considered preceding safe introduction of TOETVA to clinical practice. Expert 


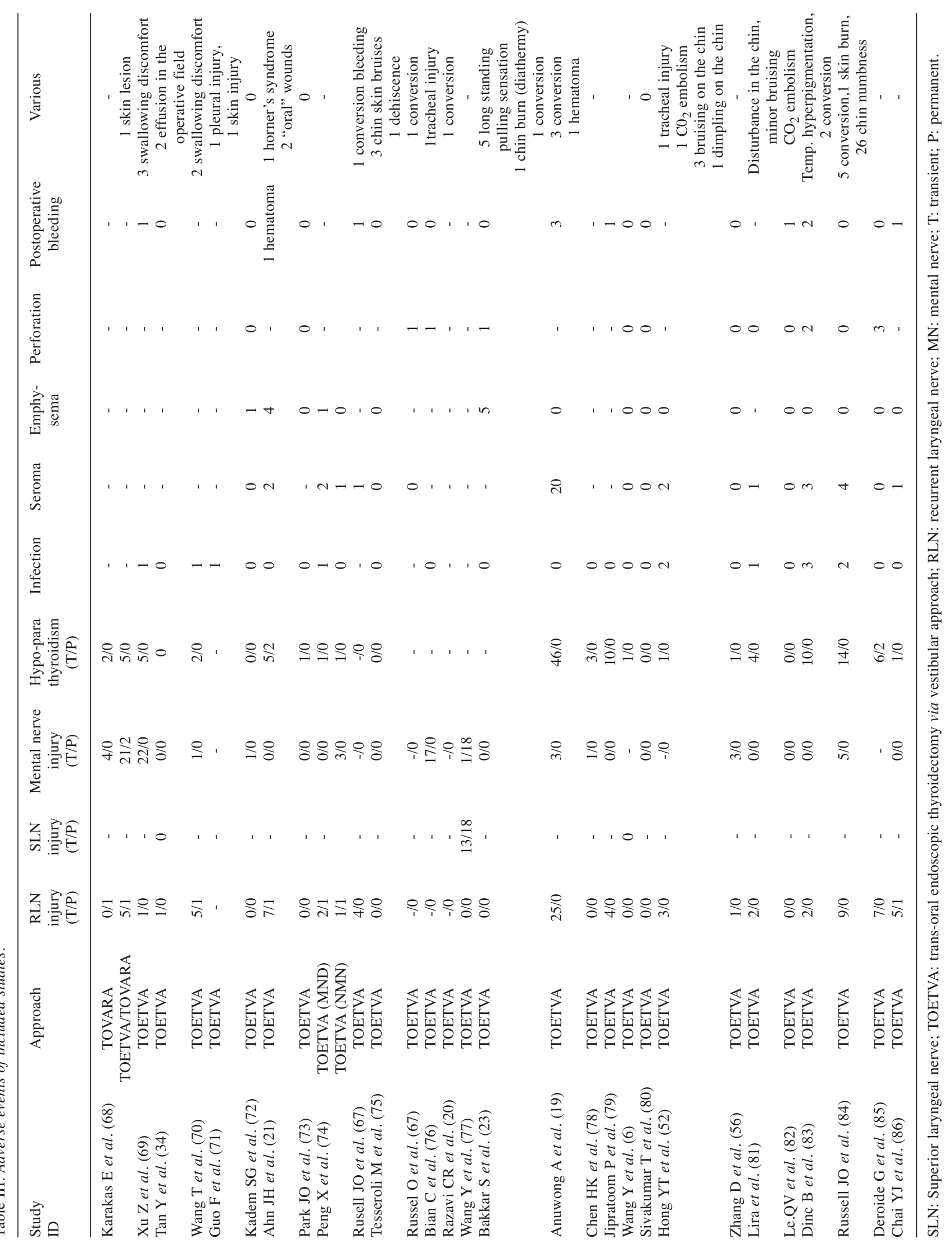


pioneers, agree on the critical need for adequate training and prevention of novel complications. Safety validation of a surgical procedure should consider both conventional and unconventional complications (23). Unconventional events are further classified into experience-related and procedure-related. Vestibular approach thyroidectomy related complications comprise new risks inherent to two-dimensional visualization, instrument's rigidity, restricted surgeon's maneuverability, and confined neck workspace (4).

TOETVA approach access thyroid gland through the oral vestibule of the lower lip transversing the premandibular space. Compared to other "remote access paths", dissection is minimized and the hypoglossal nerve is not in the operative field (24). This review focuses in TOETVArelated technical and safety issues in an attempt to draw procedure's identity.

\section{Nerve Injuries}

Although most of the nerve injuries are of the transient clinical course, they consist one of the main inherent complications experienced postoperatively by the patient.

Mental nerve injury. Mental nerve (MN) is a sensory nerve providing sensation to the front of the chin and lower lip, buccal gingivae of the mandibular anterior teeth and premolars. It is a common complication with a prevalence ranging $1-5 \%$ (25), more often transient, lateral or bilateral, related with site of working trocar placement. It results in postoperative decreased lower lip/chin sensation (numbness and/or paresthesia and/or inability to sense hot liquids).

MN palsy was early reported with an overall incidence of $4.3 \%(26,27)$. In this review, in a total of 1,887 patients, $\mathrm{MN}$ injury was recorded in 102 patients $(5.8 \%), 82$ transient $(80.4 \%)$ and the rest 20 permanent (19.6\%).

Repositioning $5 \mathrm{~mm}$ port incisions to the vestibular mucosa just in the inner aspect of the inferior lip lateral to the level of the canines might spare tract of $\mathrm{MN}$ and avoid this complication $(4,25)$. The clinical condition of altered sensation in the innervated area might persist for more than 6 months and usually occurs with other sensations such as prickling pain tingling or burning $(23,26,27)$.

Recurrent laryngeal nerve injury. Of paramount importance, in any thyroid surgical procedure, is localization and preservation of recurrent laryngeal nerve (RLN). Prevalence of transient and permanent RLN injury in conventional open thyroidectomy ranges from $2.11 \%$ to $11.8 \%$ and from $0.2 \%$ to $5.9 \%$ respectively $(2,22)$. In this review, in a total of 1887 patients, RLN injury was recorded in 85 patients $(4.5 \%), 79$ transient $(92.9 \%)$ and the remaining 6 permanent $(7.1 \%)$.

Attributed to a high definition augmented (X6-X10) "up to down" vision of endoscopic methods, the RLN is rather easily and clearly identified at its most constant location (its insertion) making TOETVA at least theoretically a safe procedure on critical neck structures (23).

However, temporary and overall RLN injury rates in TOETVA seem to be comparable or slightly higher than open procedures $(22,25)$. In the majority or reported TOETVAassociated RLN injuries, full recovery of vocal cord function was observed $(2,24,28)$. Others proposed intraoperative neuromonitoring in TOETVA procedures with good results (29). At present, limited experience and number of patients preclude firm conclusions regarding a provisional prophylactic effect of neuromonitoring in RLN injury. Intraoperative nerve monitoring (IONM) requires training, equipment, troubleshooting algorithms, and training of both surgeons and anesthesiologists. Until then, further trials are needed to elucidate IONM's role in nerve protection $(29,30)$.

External branch superior laryngeal nerve injury. "Voice symptoms" attributed to injury of the external branch of the superior laryngeal nerve (EBSLN) can occur during dissection in upper thyroid pole area. The external laryngeal nerve is the sole motor nerve supply to the cricothyroid muscle, which is the tensor of vocal folds and raises the pitch of voice. Post-thyroidectomy EBSLN injury symptoms include voice fatigue, breathy voice, and a decrease in voice range. EBSLN injury is sometimes difficult to recognize clinically and its electromyographic incidence ranges from $0 \%$ to $58 \%$ (31). During meticulous dissection of 1.5 to 2.0 $\mathrm{cm}$ of the distal end of the superior thyroid vessels, the external branch of SLN must be recognized and preserved (32). EBSLN can be either visually identified and preserved or functionally localized with the assistance of IONM (cricothyroid muscle twitch) $(33,34)$. In this review, in a total of 1,887 patients, EBSLN injury was recorded in 31 patients (1.9\%), 13 transient (41.9\%) and the rest permanent $(58.1 \%)$. Despite high quality vision during TOETVA, trivial over-dissection of the upper pole might explain the abovementioned percentages of this nerve injury.

\section{Hypoparathyroidism and Hypocalcemia}

Hypoparathyroidism, almost solely transient, is one of the commonest complications in thyroid surgery. For obvious reasons, hypocalcemia an indirect index of parathyroid dysfunction, is more common in total thyroidectomy. Theoretically, since partial "ectomies" (lobectomy, nodule ectomy) comprise the majority of TOETVA operations, low percentages of hypoparathyroidism are anticipated $(16,20)$. In our review, transient hypoparathyroidism occurred in $6.11 \%$ (range $=0.94-22.2 \%$ ) and permanent in $0.21 \%$ (range $=1.33-2.22 \%$ ). These results are comparable to those of standard open thyroidectomy (transient range $=0-11 \%$, permanent range $=0-5.7 \%)(2,35-37)$. Fewins et al. (38) 
reported an incidence of hypoparathyroidism in thyroid surgery between $6.9 \%$ and $46 \%$. Reports of permanent hypoparathyroidism are scarce (39). When a lobectomy is attempted via TOETVA, cutting the gland at midline and proceeding dissection of the lobe to be removed from medial to lateral increase the risk for parathyroid damage. This method might explain considerable rates of calcium metabolism disturbance even in lobectomies. Overzealous application of energy base devises could play a role in transient hypoparathyroid dysfunction through a mechanism of thermic shock.

\section{Skin Complications}

Minor injuries to the skin are not a surprise after TOETVA. Ecchymosis of the chin and anterior neck are common in the immediate postoperative period and resolve within 1-2 weeks $(21,23,40,41)$. Other skin damages include tears at the lip commissures from traction and piercing of the skin caused by the Veress needle, electrocautery, or even because of the use of clamps during dissection of the superior neck flap (42). Flap perforation comprises an unconventional experience-related complication occurring while dissecting centrally through the mentalis muscle down to the tip of the chin (23). Dimpling on the chin, sometimes permanent, at the site of trocar insertion has also been reported, especially if the trocar is inserted near the level of the skin. In our review population of 1887 subjects, skin complications were skin flap perforation $(n=8)$ and skin bruise/injury/dimpling $(n=16)$. Although rare, these complications directly and obviously visible to the patient undermine cosmetic expectations and ruins sensation of well-being.

\section{Seroma Formation, Hematoma, Subcutaneous Emphysema}

Seroma is a minor complication, occurring in $3.5 \%$ to $5 \%$ of published cases ( $n=36$ in our review or $36 / 1,887: 1.91 \%$ ) Its risk increases with the size of flap created to provide adequate working space; aspiration is the indicated treatment option without further sequela $(2,43)$. Hematomas are even rarer, although this might be an underestimate due to limited pertinent literature (42). In our review among 1887 patients, $10(0.53 \%)$ suffered postoperative bleeding or hematoma.

Subcutaneous emphysema should be expected intraoperatively or postoperatively in most patients because of insufflation. Almost always is self-limited and resolves within 3-5 days $(39,44)$. Presentation may be mild, with crepitus confined in the neck area, and usually diminishes in 6-12 hours (44). It may occur despite proper surgical technique and gas flow rate and pressure settings are the most important causal factors (44-49). In our review, 11 (0.58\%) patients were reported to suffer subcutaneous emphysema.

\section{Infection}

Based on the Centers for disease control and prevention (CDC) wound classification, TOETVA operation is characterized as a clean-contaminated one. The bacterial flora of the oral cavity is diverse comprising both gram positive aerobic and anaerobic bacteria (50). As such, perioperative antibiotic coverage against polymicrobial flora of the mouth is recommended $(2,24,50)$. Amoxicillin-sulbactam or cefazolin combined with clindamycin or metronidazole consist logical choices (50). Careful oral preparation, meticulous technique minimizing tissue trauma and dead space eliminate risk of infection (19, 51). A concomitant infectious process (i.e., periodontitis, tooth abscess etc.) consists a contraindication for TOETVA until cured. Fortunately, infection rates reported at TOETVA series are negligible (2). This agrees with the 12 cases out of 1,887 patients identified in our review $(0.64 \%)$.

\section{$\mathrm{CO}_{2}$ Related Complications}

Carbon dioxide embolism is a potential serious complication scarcely reported $(46,52,53)$. In our review two cases of this ominous event were recorded among 1887 patients. Either vessel, (especially the vein), micro or macro lacerations while dissecting tissues to create essential "working space", or prolonged high insufflation pressure consist the two main mechanisms promoting entrance of $\mathrm{CO}_{2}$ into the circulation (23). Insufflation-related adverse events also include pneumomediastinum, pneumothorax or excessive hypercarbia. Continuous end tidal $\mathrm{CO}_{2}$ (et $\mathrm{CO}_{2}$ ) monitoring by the anesthesiologist (goal <35), $\mathrm{CO}_{2}$ flow rates <15 1/min, $\mathrm{CO}_{2}$ pressure $6 \mathrm{mmHg}$, intermitted release of gas, precise dissection under subplatysmal plane, and meticulous hemostasis are key proposals to minimize $\mathrm{CO}_{2}$ related complications (41, 46-48, 54-56). Gasless TOETVA utilized by a special retractor has also been invented as an alternative to avoid $\mathrm{CO}_{2}$ related complications (4). Following extubation, close monitoring and observation in the recovery room is strongly recommended to ensure safe return to homeostasis $(39,49)$.

\section{Pain Pulling Sensation and Neck Swallowing Disorders}

It seems that there is a short- and long-term difference in interpretation of pain comparing open thyroidectomy approach (OTA) with TOETVA. In terms of intensity, as assessed by relevant questionnaires/survey tools such as VAS, TOETVA- and OTA- related-postoperative pain was marginally different in terms of statistical significance but of minimum clinical importance (52). TOETVA is also linked with different nature of pains such as "brushing teeth", lower lip or chin pain. Interestingly, TOETVA is reported to produce reduced cervical back pain as less head 
hyperextension is essential compared to OTA. Neck pain is also claimed to be less if the right subplatysmal plane is entered as a smaller number of pain receptors are located in the area compared to skin and subcutaneous level (56). Swallowing pain is reported to be equivalent or even lower in TOETVA patients compared with OTA $(22,25,56)$.

Patients undergoing TOETVA repeatedly report a "pulling sensation" below the lower jaw, along the area which coincides with the surgical track created during the surgical procedure. It has been defined as a feeling, a complaint, not linked with a specific clinical sign such as skin retraction or dimpling. It is postulated that extensive dissection and consequent fibrosis might explain this sensation which gradually disappears within 6 months following surgery. Although benign, this bothersome inherent-to-TOETVA symptom affects patient's quality of life and is referred as a serious reason of regretting their choice to select this approach $(4,23)$. In this current review of 1,887 subjects, only 5 patients experienced intractable long standing pulling sensation, while the rest 1,882 became progressively asymptomatic or acquainted with this symptom. Another five patients reported excessive swallowing discomfort and 36 of them chin numbness, the majority of which faded in time.

\section{Specimen Extraction, Size Restrictions}

Thyroid specimen size is a determinant factor in choosing the endoscopic vestibular approach $(25,57)$. Oncologic reasons, (i.e., violation of tumor capsule), and mechanical-technical issues (i.e., size of midline intraoral incision, tightness of tissue in chin area), constitute limiting factors and dictate definition of exclusion criteria. Intending to preserve a malignant specimen intact to avoid spillage (58), ensure "pathology readability" and minimize surgical trauma, an optimum specimen size of $\leq 20 \mathrm{~mm}$ and a volume $\leq 30 \mathrm{ml}$ is generally suggested as a reasonable limit $(58,36)$ even though larger dimensions have been attempted and proved feasible $(19,23,40,41,54,55,59,60)$. In our review, mean dimension of extracted specimens was expressed either in maximum axis length/diameter $(2.85 \pm 1.98 \mathrm{~cm})$ or in volume $(30.11 \pm 18.74$ $\mathrm{ml}$ ). To become extractable, larger in size or hard in consistency specimens warrant fragmentation at the provisional expense of oncologic safety and specimen quality, thus violating size limits should be avoided (58).

\section{Operative Time and Hospital Stay}

Operative time of TOETVA, although variable among reports, is longer compared to OT (19) but shorter than other endoscopic techniques (retro auricular, axilla) $(22,25,61$ 63). In various reports, mean operative time varies considerably from less than $100 \min (19,40,41,55)$ to more than $200 \min (28,54,64)$. Surgeon's experience and shape of the mandible have been suggested as main determinants of operative time in TOETVA. When reaching twenty cases in learning curve, operative time should decrease $(55,63)$. When the mandible has a long and narrow basal arch operation time is prolonged compared to that in cases with a short and wide arch (65). Port placement and flap dissection to create working space are time consuming especially if the surgeon is not familiar with endoscopic instruments and techniques. In our review, median operative time in minutes was $130 \pm 36.19$.

Length of hospital stay does not seem to differ among TOETVA and OT but several factors may produce wide variability $(22,25)$. Different treatment guidelines, health insurance policies, economic constraints, patient's culture or personal expectations determine length of hospital time. Series from USA or Europe report discharge after an overnight stay while those of eastern origin usually after 48-72 hours (40, 66). In our review median length of hospital stay in days was 3.15 \pm 1.47 . As more experience builds, and perioperative management improves hospital stay will decrease (61).

\section{Conclusion}

In this review, available data relevant to $\operatorname{TOETV}(\mathrm{R}) \mathrm{A}$ were extracted from case series and/or cohort studies. Twentyeight studies, the majority of which were of Eastern hemisphere origin, were analyzed in this review. Nineteen were case series and nine cohorts summing up to 1,887 patients. Recurrent and superior laryngeal nerve injury, hypoparathyroidism, trauma related complications, operative time, length of hospital stay, pain and postoperative discomfort seem to be acceptable and comparable with open approach. Acceptable safety profile of TOETVA seems to be also valid regarding inherent complications such as $\mathrm{CO}_{2}$ related (emphysema, embolism).

Open thyroid operations remain the gold standard to compare with any novel procedure. Such a comparison in the context of randomized trials remains a future challenge. Until then, novel techniques such as TOETVA are tested in few specialized centers, driving evolution in the field (4). Anatomic considerations (jaw shape), obesity, patient's culture, health policies, and economics formulate different evolution pathways between the East and West.

Keeping in mind the low level of evidence available, it could be stated that TOETVA is at least not inferior, by means of safety and outcome, compared to OT. It is also realized that it is a highly technically demanding operation with a steep learning curve, requiring previous endoscopic experience and structured training. The number of cases required to achieve minimum mastery is fifteen to twenty in endoscopic experienced operators $(20,67)$. Cadaveric or virtual reality simulation trainings are currently under validation (4). The procedure should not be undertaken by 
unfamiliar teams in the absence of mentoring and training protocols $(2,26)$.

In conclusion, this review suggests that TOETVA (or TORTVA) may be a safe treatment choice-approach for selected thyroid operative procedures in selected patients. Low level of evidence upon which this review was built is constrictive regarding reliability. Precise common terminology and clear indications remain to be defined. At present, structured training programs, evolution of instrumentation and equipment and analysis of data accumulated under the umbrella of official endocrine surgery associations is the way forward $(61,67)$. Finally, apart from cosmetic, other substantial reasons remain to be clarified before investing and adopting this skill demanding new operation.

\section{Conflicts of Interest}

The Authors declare that they have no conflicts of interest in relation to this study.

\section{Authors' Contributions}

E.A contributed by researching electronic databases, reading and sorting articles, and tabularizing results. G.D. contributed by reading, writing and editing this manuscript. E.S. contributed by conceiving the idea and approving this manuscript. G.T., D.D, N.N. contributed by reading and approving the manuscript.

\section{References}

1 Park JH, Bilegsaikhan SE and Suh YJ: A novel technique for performing transoral endoscopic thyroidectomy vestibular approach (TOETVA): A single-port platform. Surg Laparose Endosc Percutan Tech 30(1): e4-e7, 2020. PMID: 31790081. DOI: $10.1097 /$ SLE.0000000000000739

2 Anuwong A, Sasanakietkul T, Jitpratoom P, Ketwong K, Kim HY, Dionigi G and Richmon JD: Transoral endoscopic thyroidectomy vestibular approach (TOETVA): indications, techniques and results. Surg Endosc 32(1): 456-465, 2018. PMID: 28717869. DOI: 10.1007/s00464-017-5705-8

3 Juarez MC, Ishii L, Nellis JC, Bater K, Huynh PP, Fung N, Darrach H, Russell JO and Ishii M: Objectively measuring social attention of thyroid neck scars and transoral surgery using eye tracking. Laryngoscope 129(12): 2789-2794, 2019. PMID: 30900247. DOI: 10.1002/lary.27933

4 Zhang D, Park D, Sun H, Anuwong A, Tufano R, Kim HY and Dionigi G: Indications, benefits and risks of transoral thyroidectomy. Best Pract Res Clin Endocrinol Metab 33(4): 101280, 2019. PMID: 31204296. DOI: 10.1016/j.beem.2019.05.004

5 Tan CT, Cheah WK and Delbridge L: "Scarless" (in the neck) endoscopic thyroidectomy (SET): an evidence-based review of published techniques. World J Surg 32(7): 1349-1357, 2008 PMID: 18360737. DOI: 10.1007/s00268-008-9555-3

6 Wang Y, Yu X, Wang P, Miao C, Xie Q, Yan H, Zhao Q, Zhang $\mathrm{M}$ and Xiang $\mathrm{C}$ : Implementation of intraoperative neuromonitoring for transoral endoscopic thyroid surgery: a preliminary report. J Laparoendosc Adv Surg Tech A 26(12): 965-971, 2016. PMID: 27585396. DOI: 10.1089/lap.2016.0291
7 Lee HY, Lee JY, Dionigi G, Bae JW and Kim HY: The efficacy of intraoperative neuromonitoring during robotic thyroidectomy: a prospective, randomized case-control evaluation. J Laparoendosc Adv Surg Tech A 25(11): 908-914, 2015. PMID: 26575249. DOI: 10.1089/lap.2014.0544

8 Miccoli P, Berti P, Raffaelli M, Materazzi G, Baldacci S and Rossi G: Comparison between minimally invasive video-assisted thyroidectomy and conventional thyroidectomy: a prospective randomized study. Surgery 130(6): 1039-1043, 2001. PMID: 11742335. DOI: $10.1067 / \mathrm{msy} .2001 .118264$

9 Miccoli P, Rago R, Massi M, Panicucci E, Metelli MR, Berti P and Minuto MN: Standard versus video-assisted thyroidectomy: objective postoperative pain evaluation. Surg Endosc 24(10): 2415-2417, 2010. PMID: 20195641. DOI: 10.1007/s00464-0100964-7

10 Dionigi G, Boni L, Rovera F, Rausei S and Dionigi R: Wound morbidity in mini-invasive thyroidectomy. Surg Endosc 25(1): 6267, 2011. PMID: 20526624. DOI: 10.1007/s00464-010-1130-y

11 Tae K, Ji YB, Song CM and Ryu J: Robotic and endoscopic thyroid surgery: Evolution and advances. Clin Exp Otorhinolaryngol 12(1): 1-11, 2019. PMID: 30196688. DOI: 10.21053/ceo.2018.00766

12 Kurumety SK, Helenowski IB, Goswami S, Peipert BJ, Yount SE and Sturgeon C: Post-thyroidectomy neck appearance and impact on quality of life in thyroid cancer survivors. Surgery 165(6): 1217-1221, 2019. PMID: 31030973. DOI: 10.1016/ j.surg.2019.03.006

13 Choi Y, Lee JH, Kim YH, Lee YS, Chang HS, Park CS and Roh MR: Impact of postthyroidectomy scar on the quality of life of thyroid cancer patients. Ann Dermatol 26(6): 693-699, 2014. PMID: 25473220. DOI: 10.5021/ad.2014.26.6.693

14 Juarez MC, Ishii L, Nellis JC, Bater K, Huynh PP, Fung N, Darrach H, Russell JO and Ishii M: Objectively measuring social attention of thyroid neck scars and transoral surgery using eye tracking. Laryngoscope 129(12): 2789-2794, 2019. PMID: 30900247. DOI: 10.1002/lary.27933

15 Felix C, Russell JO, Juman S and Medford S: Cervical scar satisfaction post conventional thyroidectomy. Gland Surg 8(6): 723-728, 2019. PMID: 32042680. DOI: $10.21037 / \mathrm{gs} .2019 .11 .17$

16 Wilhelm $\mathrm{T}$ and Metzig A: Endoscopic minimally invasive thyroidectomy (eMIT): a prospective proof-of-concept study in humans. World J Surg 35(3): 543-551, 2011. PMID: 21088839. DOI: $10.1007 / \mathrm{s} 00268-010-0846-0$

17 Yi JW, Yoon SG, Kim HS, Yu HW, Kim SJ, Chai YJ, Choi JY and Lee KE: Transoral endoscopic surgery for papillary thyroid carcinoma: initial experiences of a single surgeon in South Korea. Ann Surg Treat Res 95(2): 73-79, 2018. PMID: 30079323. DOI: 10.4174/astr.2018.95.2.73

18 Russell JO, Sahli ZT, Shaear M, Razavi C, Ali K and Tufano RP: Transoral thyroid and parathyroid surgery via the vestibular approach-a 2020 update. Gland Surg 9(2): 409-416, 2020. PMID: 32420266. DOI: 10.21037/gs.2020.03.05

19 Anuwong A, Ketwong K, Jitpratoom P, Sasanakietkul T and Duh QY: Safety and outcomes of the transoral endoscopic thyroidectomy vestibular approach. JAMA Surg 153(1): 21-27, 2018. PMID: 28877292. DOI: 10.1001/jamasurg.2017.3366

20 Razavi CR, Vasiliou E, Tufano RP and Russell JO: Learning curve for transoral endoscopic thyroid lobectomy. Otolaryngol Head Neck Surg 159(4): 625-629, 2018. PMID: 30126330. DOI: $10.1177 / 0194599818795881$ 
21 Ahn JH and Yi JW: Transoral endoscopic thyroidectomy for thyroid carcinoma: outcomes and surgical completeness in 150 single-surgeon cases. Surg Endosc 34(2): 861-867, 2020. PMID: 31139987. DOI: 10.1007/s00464-019-06841-8

22 Witzel K, von Rahden BH, Kaminski C and Stein HJ: Transoral access for endoscopic thyroid resection. Surg Endosc 22(8): 1871-1875, 2008. PMID: 18163167. DOI: 10.1007/s00464-0079734-6

23 Bakkar S, Al Hyari M, Naghawi M, Corsini C and Miccoli P: Transoral thyroidectomy: a viable surgical option with unprecedented complications-a case series. J Endocrinol Invest 41(7): 809-813, 2018. PMID: 29243180. DOI: 10.1007/s40618017-0808-6

24 Anuwong A: Transoral endoscopic thyroidectomy vestibular approach: a series of the first 60 human cases. World J Surg 40(3): 491-497, 2016. PMID: 26546193. DOI: 10.1007/s00268015-3320-1

25 Kim HK, Chai YJ, Dionigi G, Berber E, Tufano RP and Kim HY: Transoral robotic thyroidectomy for papillary thyroid carcinoma: Perioperative outcomes of 100 consecutive patients. World J Surg 43(4): 1038-1046, 2019. PMID: 30539261. DOI: 10.1007/s00268-018-04877-w

26 Colella G, Giudice A, Siniscalchi G, Falcone U and Guastafierro S: Chin numbness: a symptom that should not be underestimated: a review of 12 cases. Am J Med Sci 337(6): 407-410, 2009. PMID: 19359984. DOI: 10.1097/MAJ.0b013e31819299fa

27 Ewbank RL: Mental nerve neuropathy. Oral Surg Oral Med Oral Pathol 50(4): 325-326, 1980. PMID: 6935583. DOI: 10.1016/ 0030-4220(80)90415-6

28 Udelsman R, Anuwong A, Oprea AD, Rhodes A, Prasad M, Sansone M, Brooks C, Donovan PI, Jannitto C and Carling T: Trans-oral vestibular endocrine surgery: a new technique in the United States. Ann Surg 264(6): e13-e16, 2016. PMID: 27649533. DOI: 10.1097/SLA.0000000000002001

29 Dionigi G, Wu CW, Tufano RP, Rizzo AG, Anuwong A, Sun H, Carcoforo P, Antonino C, Portinari M and Kim HY: Monitored transoral endoscopic thyroidectomy via long monopolar stimulation probe. J Vis Surg 4: 24, 2018. PMID: 29445610. DOI: $10.21037 /$ jovs.2017.12.25

30 Dionigi G, Boni L, Rovera F, Bacuzzi A and Dionigi R: Neuromonitoring and video-assisted thyroidectomy: a prospective, randomized case-control evaluation. Surg Endosc 23(5): 996-1003, 2009. PMID: 18806939. DOI: 10.1007/s00464008-0098-3

31 Gavid M, Dubois MD, Larivé E and Prades JM: Superior laryngeal nerve in thyroid surgery: anatomical identification and monitoring. Eur Arch Otorhinolaryngol 274(9): 3519-3526, 2017. PMID: 28687919. DOI: 10.1007/s00405-017-4666-9

32 Loré JM Jr, Kokocharov SI, Kaufman S, Richmond A and Sundquist N: Thirty-eight-year evaluation of a surgical technique to protect the external branch of the superior laryngeal nerve during thyroidectomy. Ann Otol Rhinol Laryngol 107(12): 10151022, 1998. PMID: 9865631. DOI: 10.1177/000348949810701204

33 Gurleyik E and Gurleyik G: Intraoperative monitoring of external branch of the superior laryngeal nerve: Functional identification, motor integrity, and its role on vocal cord function. J Invest Surg 31(6): 509-514, 2018. PMID: 28952819. DOI: $10.1080 / 08941939.2017 .1362489$

34 Tan Y, Guo B, Deng X, Ding Z, Wu B, Niu Y, Hou J, Zhang Y and Fan Y: Transoral endoscopic selective lateral neck dissection for papillary thyroid carcinoma: a pilot study. Surg Endosc 34(12): 5274-5282, 2020. PMID: 31834511. DOI: 10.1007/ s00464-019-07314-8

35 Song CM, Jung JH, Ji YB, Min HJ, Ahn YH and Tae K: Relationship between hypoparathyroidism and the number of parathyroid glands preserved during thyroidectomy. World J Surg Oncol 12: 200, 2014. PMID: 25000948. DOI: 10.1186/1477-7819-12-200

36 Ywata de Carvalho A, Chulam TC and Kowalski LP: Long-term results of observation $v s$. prophylactic selective level VI neck dissection for papillary thyroid carcinoma at a cancer center. JAMA Otolaryngol Head Neck Surg 141(7): 599-606, 2015. PMID: 25997016. DOI: 10.1001/jamaoto.2015.0786

37 Selberherr A, Scheuba C, Riss P and Niederle B: Postoperative hypoparathyroidism after thyroidectomy: efficient and costeffective diagnosis and treatment. Surgery 157(2): 349-353, 2015. PMID: 25532435. DOI: 10.1016/j.surg.2014.09.007

38 Fewins J, Simpson CB and Miller FR: Complications of thyroid and parathyroid surgery. Otolaryngol Clin North Am 36(1): 189206, x, 2003. PMID: 12803016. DOI: 10.1016/s00306665(02)00129-9

39 Shan L and Liu J: A systemic review of transoral thyroidectomy. Surg Laparosc Endosc Percutan Tech 28(3): 135-138, 2018. PMID: 29389814. DOI: 10.1097/SLE.0000000000000512

40 Dionigi G, Bacuzzi A, Lavazza M, Inversini D, Boni L, Rausei S, Kim HY and Anuwong A: Transoral endoscopic thyroidectomy: preliminary experience in Italy. Updates Surg 69(2): 225-234, 2017. PMID: 28405949. DOI: 10.1007/s13304017-0436-x

41 Yang J, Wang C, Li J, Yang W, Cao G, Wong HM, Zhai H and Liu W: Complete endoscopic thyroidectomy via oral vestibular approach versus areola approach for treatment of thyroid diseases. J Laparoendosc Adv Surg Tech A 25(6): 470-476, 2015. PMID: 26061132. DOI: 10.1089/lap.2015.0026

42 Fernandez-Ranvier G, Meknat A, Guevara DE and Inabnet WB 3rd: Transoral endoscopic thyroidectomy vestibular approach. JSLS 23(4): e2019.00036, 2019. PMID: 31719772. DOI: $10.4293 /$ JSLS .2019 .00036

43 Shan CX, Zhang W, Jiang DZ, Zheng XM, Liu S and Qiu M: Prevalence, risk factors, and management of seroma formation after breast approach endoscopic thyroidectomy. World J Surg 34(8): 1817-1822, 2010. PMID: 20414774. DOI: 10.1007/ s00268-010-0597-y

44 Zhang D, Wu CW, Inversini D, Kim HY, Anuwong A, Bacuzzi $\mathrm{A}$ and Dionigi G: Lessons learned from a faulty transoral endoscopic thyroidectomy vestibular approach. Surg Laparosc Endosc Percutan Tech 28(5): e94-e99, 2018. PMID: 29975356. DOI: $10.1097 /$ SLE.0000000000000555

45 Bellantone R, Lombardi CP, Rubino F, Perilli V, Sollazzi L, Mastroianni G and Gagner M: Arterial PCO2 and cardiovascular function during endoscopic neck surgery with carbon dioxide insufflation. Arch Surg 136(7): 822-827, 2001. PMID: 11448398. DOI: $10.1001 /$ archsurg.136.7.822

46 Kim SH, Park KS, Shin HY, Yi JH and Kim DK: Paradoxical carbon dioxide embolism during endoscopic thyroidectomy confirmed by transesophageal echocardiography. J Anesth 24(5): 774-777, 2010. PMID: 20683735. DOI: 10.1007/s00540-0100992-4

47 Ochiai R, Takeda J, Noguchi J, Ohgami M and Ishii S: Subcutaneous carbon dioxide insufflation does not cause 
hypercarbia during endoscopic thyroidectomy. Anesth Analg 90(3): 760-762, 2000. PMID: 10702471. DOI: 10.1097/ 00000539-200003000-00046

48 Gottlieb A, Sprung J, Zheng XM and Gagner M: Massive subcutaneous emphysema and severe hypercarbia in a patient during endoscopic transcervical parathyroidectomy using carbon dioxide insufflation. Anesth Analg 84(5): 1154-1156, 1997. PMID: 9141952. DOI: 10.1097/00000539-199705000-00040

49 Anuwong A: Strategy to prevent subcutaneous emphysema and gas insufflation-related complications in transoral endoscopic thyroidectomy vestibular approach: Reply. World J Surg 41(10): 2649-2650, 2017. PMID: 28474274. DOI: 10.1007/s00268-0174042-3

50 Salmerón-Escobar JI and del Amo-Fernández de Velasco A: Antibiotic prophylaxis in Oral and Maxillofacial Surgery. Med Oral Patol Oral Cir Bucal 11(3): E292-E296, 2006. PMID: 16648771 .

51 Liu N, Chen B, Li L, Zeng Q and Lv B: Subplatysmal or subfascial approach in totally endoscopic thyroidectomy has better postoperative efficacy for voice, sensory, swallowing symptoms and cosmetic result. Cohort study. Int J Surg 60: 2227, 2018. PMID: 30389533. DOI: 10.1016/j.ijsu.2018.10.034

52 Hong YT, Ahn JH, Kim JH, Yi JW and Hong KH: Biinstitutional experience of transoral endoscopic thyroidectomy: Challenges and outcomes. Head Neck 42(8): 2115-2122, 2020. PMID: 32212365. DOI: 10.1002/hed.26153

53 Fu J, Luo Y, Chen Q, Lin F, Hong X, Kuang P, Yan W, Wu G and Zhang Y: Transoral endoscopic thyroidectomy: Review of 81 cases in a single institute. J Laparoendosc Adv Surg Tech A 28(3): 286-291, 2018. PMID: 29297741. DOI: 10.1089/lap.2017.0435

54 Nakajo A, Arima H, Hirata M, Mizoguchi T, Kijima Y, Mori S, Ishigami S, Ueno S, Yoshinaka H and Natsugoe S: Trans-Oral Video-Assisted Neck Surgery (TOVANS). A new transoral technique of endoscopic thyroidectomy with gasless premandible approach. Surg Endosc 27(4): 1105-1110, 2013. PMID: 23179070. DOI: $10.1007 / \mathrm{s} 00464-012-2588-6$

55 Wang C, Zhai H, Liu W, Li J, Yang J, Hu Y, Huang J, Yang W, Pan Y and Ding H: Thyroidectomy: a novel endoscopic oral vestibular approach. Surgery 155(1): 33-38, 2014. PMID: 23890962. DOI: $10.1016 /$ j.surg.2013.06.010

56 Zhang D, Caruso E, Sun H, Anuwong A, Tufano R, Materazzi G, Dionigi $G$ and Kim HY: Classifying pain in transoral endoscopic thyroidectomy. J Endocrinol Invest 42(11): 13451351, 2019. PMID: 31187465. DOI: 10.1007/s40618-01901071-0

57 You JY, Kim HY, Chai YJ, Kim HK, Anuwong A, Tufano RP and Dionigi G: Transoral robotic thyroidectomy versus conventional open thyroidectomy: comparative analysis of surgical outcomes in thyroid malignancies. J Laparoendosc Adv Surg Tech A 29(6): 796-800, 2019. PMID: 30785841. DOI: 10.1089/lap.2018.0587

$58 \mathrm{Wu}$ YJ, Chi SY, Elsarawy A, Chan YC, Chou FF, Lin YC, Wee SY, Pan CC, Cheng BC and Lin CC: What is the appropriate nodular diameter in thyroid cancer for extraction by transoral endoscopic thyroidectomy vestibular approach without breaking the specimens? A surgicopathologic study. Surg Laparosc Endosc Percutan Tech 28(6): 390-393, 2018. PMID: 30074529. DOI: $10.1097 /$ SLE.0000000000000563

59 Park JO and Sun DI: Transoral endoscopic thyroidectomy: our initial experience using a new endoscopic technique. Surg
Endosc 31(12): 5436-5443, 2017. PMID: 28523362. DOI: 10.1007/s00464-017-5594-X

60 Chen S, Zhao M and Qiu J: Transoral vestibule approach for thyroid disease: a systematic review. Eur Arch Otorhinolaryngol 276(2): 297-304, 2019. PMID: 30460401. DOI: 10.1007/s00405018-5206-y

61 Johri G, Chand G, Mishra A, Mayilvaganan S, Agarwal G, Agarwal A and Mishra SK: Endoscopic versus conventional thyroid surgery: A comparison of quality of life, cosmetic outcomes and overall patient satisfaction with treatment. World J Surg 44(12): 4118-4126, 2020. PMID: 32789681. DOI: 10.1007/s00268-020-05732-7

62 Jeong JJ, Kang SW, Yun JS, Sung TY, Lee SC, Lee YS, Nam $\mathrm{KH}$, Chang HS, Chung WY and Park CS: Comparative study of endoscopic thyroidectomy versus conventional open thyroidectomy in papillary thyroid microcarcinoma (PTMC) patients. J Surg Oncol 100(6): 477-480, 2009. PMID: 19653245. DOI: $10.1002 /$ jso.21367

63 Liu S, Qiu M, Jiang DZ, Zheng XM, Zhang W, Shen HL and Shan CX: The learning curve for endoscopic thyroidectomy: a single surgeon's experience. Surg Endosc 23(8): 1802-1806, 2009. PMID: 19247710. DOI: 10.1007/s00464-009-0332-7

64 Kim HY, Chai YJ, Dionigi G, Anuwong A and Richmon JD: Transoral robotic thyroidectomy: lessons learned from an initial consecutive series of 24 patients. Surg Endosc 32(2): 688-694, 2018. PMID: 28726141. DOI: 10.1007/s00464-017-5724-5

65 Shulutko AM, Semikov VI, Osmanov EG, Gryaznov SE, Gorbacheva AV, Patalova AR, Mansurova GT and Kazaryan AM: Evaluation criteria and surgical technique for transoral access to the thyroid gland: experimental study. J Invest Surg 32(5): 421-427, 2019. PMID: 29370544. DOI: 10.1080/ 08941939.2018.1424271

66 Witzel K, Messenbaeck F, Weitzendorfer M and Benhidjeb T: Transoral thyroidectomy: limitations, patients' safety, and own experiences. Updates Surg 69(2): 193-198, 2017. PMID: 28573543. DOI: $10.1007 / \mathrm{s} 13304-017-0457-5$

67 Russell JO, Razavi CR, Garstka ME, Chen LW, Vasiliou E, Kang SW, Tufano RP and Kandil E: Remote-access thyroidectomy: A multi-institutional North American experience with transaxillary, robotic facelift, and transoral endoscopic vestibular approaches. J Am Coll Surg 228(4): 516-522, 2019. PMID: 30586640. DOI: 10.1016/j.jamcollsurg.2018.12.005

68 Karakas E, Klein G and Schopf S: Transoral thyroid surgery vestibular approach: does size matter anymore? J Endocrinol Invest 43(5): 615-622, 2020. PMID: 31989449. DOI: 10.1007/ s40618-019-01149-9

69 Xu Z, Song J, Wang Y, Tan L, Sun S and Meng Y: A comparison of transoral vestibular and bilateral areolar endoscopic thyroidectomy approaches for unilateral papillary thyroid microcarcinomas. Wideochir Inne Tech Maloinwazyjne 14(4): 501-508, 2019. PMID: 31908695. DOI: 10.5114/wiitm.2019. 84759

70 Wang T, Wu Y, Xie Q, Yan H, Zhou X, Yu X, Chen Y, Xiang C, Yan H, Zhao Q, Zhang M, Qi M, Wang P and Wang Y: Safety of central compartment neck dissection for transoral endoscopic thyroid surgery in papillary thyroid carcinoma. Jpn J Clin Oncol 50(4): 387-391, 2020. PMID: 31829423. DOI: 10.1093/ jjco/hyz195

71 Guo F, Wang W, Zhu X, Xiang C, Wang P and Wang Y: Comparative study between endoscopic thyroid surgery via the 
oral vestibular approach and the areola approach. J Laparoendosc Adv Surg Tech A 30(2): 170-174, 2020. PMID: 31621490. DOI: 10.1089/lap.2019.0562

72 Kadem SG, Habash SM and Jasim AH: Transoral Endoscopic Thyroidectomy via Vestibular Approach: A series of the first ten cases in Iraq. Sultan Qaboos Univ Med J 19(1): e68-e72, 2019. PMID: 31198599. DOI: 10.18295/squmj.2019.19.01.013

73 Park JO, Park YJ, Kim MR, Sun DI, Kim MS and Koh YW: Gasless transoral endoscopic thyroidectomy vestibular approach (gasless TOETVA). Surg Endosc 33(9): 3034-3039, 2019. PMID: 31087173. DOI: 10.1007/s00464-019-06826-7

74 Peng X, Li Z, Li H, Peng W, Zhou X, Song D, Zhou B and Lv $\mathrm{C}$ : The clinical application of mental nerve dissection in transoral endoscopic thyroidectomy via an oral vestibular approach. Surg Endosc 34(1): 153-158, 2020. PMID: 30877568. DOI: $10.1007 / \mathrm{s} 00464-019-06743-9$

75 Tesseroli MAS, Spagnol $M$ and Sanabria Á: Transoral endoscopic thyroidectomy by vestibular approach (TOETVA): initial experience in Brazil. Rev Col Bras Cir 45(5): e1951, 2018. PMID: 30462826. DOI: 10.1590/0100-6991e-20181951

76 Bian C, Liu H, Yao XY, Wu SP, Wu Y, Liu C and Huang TS: Complete endoscopic radical resection of thyroid cancer via an oral vestibule approach. Oncol Lett 16(5): 5599-5606, 2018. PMID: 30344714. DOI: 10.3892/ol.2018.9369

77 Wang Y, Zhang Z, Zhao Q, Xie Q, Yan H, Yu X, Xiang C, Zhang $\mathrm{M}$ and Wang P: Transoral endoscopic thyroid surgery via the trivestibular approach with a hybrid space-maintaining method: A preliminary report. Head Neck 40(8): 1774-1779, 2018. PMID: 29603475. DOI: $10.1002 /$ hed.25157

78 Chen HK, Chen CL, Wen KS, Lin YF, Lin KY and Uen YH: Application of transoral continuous intraoperative neuromonitoring in natural orifice transluminal endoscopic surgery for thyroid disease: a preliminary study. Surg Endosc 32(1): 517-525, 2018. PMID: 28643050. DOI: 10.1007/s00464017-5656-0

79 Jitpratoom P, Ketwong K, Sasanakietkul T and Anuwong A: Transoral endoscopic thyroidectomy vestibular approach (TOETVA) for Graves' disease: a comparison of surgical results with open thyroidectomy. Gland Surg 5(6): 546-552, 2016. PMID: 28149798. DOI: $10.21037 / \mathrm{gs} .2016 .11 .04$
80 Sivakumar T and Amizhthu RA: Transoral endoscopic total thyroidectomy vestibular approach: A case series and literature review. J Minim Access Surg 14(2): 118-123, 2018. PMID: 29067943. DOI: 10.4103/jmas.JMAS_3_17

81 Lira RB, Ramos AT, Nogueira RMR, de Carvalho GB, Russell JO, Tufano RP and Kowalski LP: Transoral thyroidectomy (TOETVA): Complications, surgical time and learning curve. Oral Oncol 110: 104871, 2020. PMID: 32619928. DOI: 10.1016/ j.oraloncology.2020.104871

82 Le QV, Ngo DQ, Tran TD and Ngo QX: Transoral endoscopic thyroidectomy vestibular approach: an initial experience in Vietnam. Surg Laparosc Endosc Percutan Tech 30(3): 209-213, 2020. PMID: 32032330. DOI: 10.1097/SLE.0000000000000764

83 Dinç B, İlker Turan M, Rıza Gündüz U and Haluk Belen N: Transoral endoscopic thyroidectomy vestibular approach (TOETVA): Our outcomes from Turkey. Turk J Surg 36(4): 340346, 2020. PMID: 33778392. DOI: 10.47717/turkjsurg. 2020.4765

84 Russell JO, Razavi CR, Shaear M, Liu RH, Chen LW, PaceAsciak P, Tanavde V, Tai KY, Ali K, Fondong A, Kim HY and Tufano RP: Transoral thyroidectomy: Safety and outcomes of 200 consecutive North American cases. World J Surg 45(3): 774-781, 2021. PMID: 33205227. DOI: 10.1007/s00268-02005874-8

85 Deroide G, Honigman I, Berthe A, Branger F, Cussac-Pillegand $\mathrm{C}$, Richa $\mathrm{H}$ and Anuwong $\mathrm{A}$ : Trans oral endoscopic thyroidectomy (TOETVA): First French experience in 90 patients. J Visc Surg 158(2): 103-110, 2021. PMID: 33676861. DOI: $10.1016 /$ j.jviscsurg.2021.02.001

86 Chai YJ, Chae S, Oh MY, Kwon H and Park WS: Transoral endoscopic thyroidectomy vestibular approach (TOETVA): Surgical outcomes and learning curve. J Clin Med 10(4): 863, 2021. PMID: 33669741. DOI: 10.3390/jcm10040863

Received September 5, 2021

Revised October 2, 2021

Accepted October 6, 2021 